\title{
Coleopterans (Hexapoda, Coleoptera) associated with canopies of Callisthene fasciculata (Spr.) Mart. (Vochysiaceae) in the Brazilian Pantanal
}

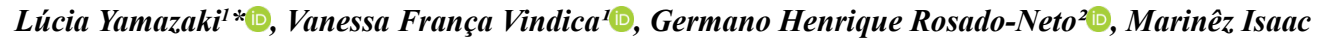 \\ Marques $^{3}$ \& L Leandro Dênis Battirola ${ }^{1}$ (1) \\ ${ }^{1}$ Universidade Federal de Mato Grosso, Instituto de Ciências Naturais, Humanas e Sociais, Programa de Pós- \\ Graduação em Ciências Ambientais, Av. Alexandre Ferronato 1.200, Setor Industrial, \\ 78557-267, Sinop, MT, Brasil. \\ ${ }^{2}$ Universidade Federal do Paraná, Departamento de Zoologia, Centro Politécnico, Curitiba, \\ PR, Brasil. \\ ${ }^{3}$ Universidade Federal de Mato Grosso, Instituto de Biociências, Programa de Pós-Graduação em Zoologia, \\ Programa de Pós-Graduação em Ecologia e Conservação da Biodiversidade, Avenida Fernando Corrêa da \\ Costa 2.367, Boa Esperança, 78060-900, Cuiabá, MT, Brasil. \\ *Corresponding author: Lúcia Yamazaki,e-mail: lucia_yamazaki_ly@hotmail.com
}

YAMAZAKI, L., VINDICA, V.F., ROSADO-NETO, G.H., MARQUES, M.I., BATTIROLA, L.D. Coleopterans (Hexapoda, Coleoptera) associated with canopies of Callisthene fasciculata (Spr.) Mart. (Vochysiaceae) in the Brazilian Pantanal. Biota Neotropica 21(1): e20200982. https://doi.org/10.1590/1676-0611-BN-2020-0982

\begin{abstract}
The study of coleopteran assemblages associated with the canopies of tropical forests can help to expand the knowledge about species diversity and the ecological patterns related to the distribution of this diversity in tropical environments, including wetlands such as the Brazilian Pantanal. In this scenario, the present study examined the effect of temporal variation on the abundance, richness and distribution of the Coleoptera assemblage associated with canopies of Callisthene fasciculata (Spr.) Mart. (Vochysiaceae) throughout the dry and high-water seasonal periods in the Northern Pantanal of Mato Grosso, Brazil. Twelve specimens of C. fasciculata were sampled between 2010 and 2011, six per seasonal period, by thermal fogging with insecticide. A total of 1,663 coleopterans were collected, consisting of 1,572 adults and 91 larvae. The adults are distributed into 38 families and 251 species or morphospecies. Chrysomelidae, Curculionidae, Nitidulidae and Tenebrionidae predominated in terms of abundance and richness. Family distribution, abundance, species richness and trophic guilds varied between the dry and high-water periods, demonstrating a relationship with the phenological conditions of $C$. fasciculata in addition to seasonality effect. In conclusion, the seasonality imposed by the hydrological regime and its influence on the phenology of $C$. fasciculata affect the structure of the coleopteran assemblage associated with the canopy of this monodominant vegetation formation in the Pantanal of Mato Grosso.
\end{abstract}

Keywords: Beetles; Biodiversity; Seasonality; Wetlands.

\section{Coleópteros (Hexapoda, Coleoptera) associados às copas de Callisthene fasciculata (Spr.) Mart. (Vochysiaceae) no Pantanal brasileiro}

Resumo: O estudo de assembleias de coleópteros associadas às copas de florestas tropicias contribui para a expansão do conhecimento sobre a diversidade de espécies e os padrões ecológicos relacionados à distribuição dessa diversidade em ambientes tropicais, incluindo áreas úmidas como o Pantanal brasileiro. Nesse cenário, o presente estudo avaliou o efeito da variação temporal sobre a abundância, riqueza e distribuição da assembleia de Coleoptera associada às copas de Callisthene fasciculata (Spr.) Mart. (Vochysiaceae) ao longo dos períodos de seca e cheia na região norte do Pantanal de Mato Grosso, Brasil. Doze exemplares de C. fasciculata foram amostrados entre 2010 e 2011, seis por período sazonal, utilizando-se termonebulização com inseticida. Um total de 1.663 coleópteros foram coletados, consistindo em 1.572 adultos e 91 larvas. Os adultos se distribuem em 38 famílias e 251 espécies e morfoespécies. Chrysomelidae, Curculionidae, Nitidulidae e Tenebrionidae predominaram em termos de abundância e riqueza. A distribuição das famílias, abundância, riqueza de espécies e agrupamentos em guildas tróficas variaram entre os períodos de seca e cheia, evidenciando uma estreita relação com as condições fenológicas de $C$. fasciculata ocasionadas pelo efeito sazonal dessa região. Conclui-se que a sazonalidade imposta pelo regime hidrológico do Pantanal e sua influência sobre a fenologia de $C$. fasciculata afetam a estrutura da assembleia de coleópteros associados às copas nessa formação monodominante no Pantanal de Mato Grosso. Palavras-chave: Áreas inundáveis; Besouros; Biodiversidade; Sazonalidade. 


\section{Introduction}

The forest canopy is habitat to a high number of organisms. Different animal assemblages occupy the niches available in those habitats according to their complexity, structure and dynamics as well as their close relationship with the maintenance of forest stability (e.g. Basset et al. 2003a, Erwin 2013, Fotis et al. 2018). In this forest stratum, the availability of a greater variety of food resources is essential for the maintenance of a high number of species such as those of the Order Coleoptera, which participate in various ecological processes in the forest canopy due to its richness and multiple food habitats (Erwin 1983, Hammond et al. 1996, Adis et al. 2010).

Studies on tree canopies have related the interaction of these insects to specific plant hosts, indicating the existence of very close evolutionary relationships between plants and coleopterans involving pollination, herbivory, seed predation, as well as activity as trophic links in food chains (Basset 1992, Ødegaard 2003, 2004, Novotny \& Basset 2005). Some coleopterans utilize those habitats in only one of the phases of their life cycle; e.g. Curculionidae and Chrysomelidae species which complete larval development in the soil and migrate to the forest canopy when adult (Adis 1988, Lawrence \& Britton 1991), or Cerambycidae species which use the plant hosts when adult and synchronize their larval development on branches fallen to the ground to the flood cycles in flooded areas like the Pantanal (Marques et al. 2014). In addition to the interactions between coleopterans and their plant hosts, these insects are widespread through aquatic and terrestrial ecosystems, constituting the most numerous and diverse Order of the Animal kingdom, where they represent 35\% of all known insects (Marinoni 2001, Casari \& Ide 2012).

Studies in the Northern Pantanal of Mato Grosso have reported the existence of Coleoptera assemblages with high species richness values associated with different terrestrial habitats (Carneiro et al. 2006, Marques et al. 2016), and plant hosts, including Attalea phalerata Mart. (Arecaceae) (Santos et al. 2003, Battirola et al. 2014), Calophyllum brasiliense Cambess. (Calophyllaceae) (Marques et al. 2007), and Vochysia divergens Pohl. (Vochysiaceae) (Marques et al. 2001, 2006). These studies also demonstrated the temporal variation of those assemblages as a function of the dry and high-water periods, which are characteristic of this Pantanal region. This confirms their complexity and importance for the maintenance of the biodiversity of this floodplain (Junk et al. 2006, 2013, Wantzen et al. 2016, Tomas et al. 2019).

In addition to the specific hydrological conditions in the northern region of the Pantanal, its landscape formed by a mosaic of forest and field units, flooded or permanently dry, makes studies on the diversity associated with these different types of habitats, fundamental to understand the dynamics of this ecosystem (Junk et al. 2006), mainly, assessing groups with high species richness as Coleoptera. In this mosaic of landscapes, monodominant forests stand out, as important elements in the Northern Pantanal region (Nunes da Cunha \& Junk 2014), as the formations of Callisthene fasciculata (Spr.) Mart. (Vochysiaceae) (Corsini \& Guarim-Neto 2000). In these forest formations, considering the specific and in-depth discussions that each taxonomic group needs, specific results to some arthropod groups associated with $C$. fasciculata canopies have already been published as spiders (Yamazaki et al. 2017), and ants (Yamazaki et al. 2016). Despite this, evaluations with other taxonomic groups are still needed to know the real richness of species present in these region.

In view of the importance of conserving wetlands to maintain the great biological diversity of those ecosystems as well as the complexities of coleopteran assemblages in the forest canopy, the present study examines the effect of temporal variation on the abundance, richness and distribution of the Coleoptera assemblage associated with C. fasciculata (Spr.) Mart. (Vochysiaceae) canopies as a function of the high-water and dry seasonal periods in the Northern Pantanal of Mato Grosso, Brazil.

\section{Materials and methods}

\section{Study area}

Sampling was carried out in a seasonally flooded monodominant forest with predominance of C. fasciculata, locally called "carvoal", in the northern region of the Pantanal of Mato Grosso, on Porto Cercado road, specifically, at the Alvorada farm (16 $26^{\prime} 56^{\prime \prime} \mathrm{S}$ and 562'3' W), in Poconé - MT, Brazil (Figure 1). The local climate is a tropical savannah characterized by dry winters and wet summers, with temperatures ranging between 22 and $32{ }^{\circ} \mathrm{C}$ (Hasenack et al. 2003), and an AW type under the Köppen classification. Annual precipitation varies between 1,000 and $1,500 \mathrm{~mm}$, with periods of rainfall below $10 \mathrm{~mm}$ occurring over several months. This region has well-defined seasons, with a rainy period between October and March and a dry period between April and September, resulting in a hydrological cycle with four distinct seasonal periods (high water, receding water, dry period and rising water) (Heckman 1998).

As discussed by Yamazaki et al. (2016, 2017), C. fasciculata is a tree that reaches between four and $15 \mathrm{~m}$ in height and has a dark, thick

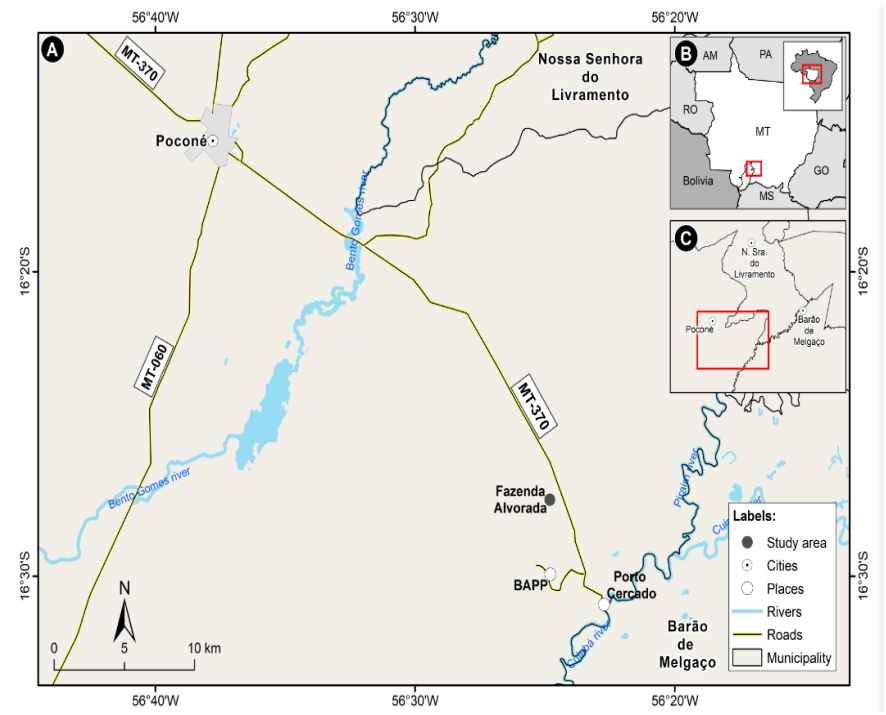

Figure 1. Location of the study area at Alvorada farm (A) in the Northern Pantanal of Mato Grosso, on Porto Cercado road, in Poconé - Mato Grosso, Brazil (B and C).

and very rough bark (Pott \& Pott 1994). The flowering period occurs between September and October, together with the dispersion of seeds generated in the previous year (Custódio et al. 2014). The species is characterized as deciduous, with no leaf fall or partial leaf fall from the rising water to the beginning of the dry period and total leaf fall at the end of the dry period. During the high-water period C. fasciculata presents well-developed foliage (Corsini \& Guarim-Neto 2000). 


\section{Methodology}

Canopy fogging was performed in 12 C. fasciculata canopies, six during the high water (February/2010) and six in the dry period (September/2011). The trees were selected during the dry and highwater periods, maintaining a minimum distance of $10 \mathrm{~m}$ between each specimen. All of them were between 10 and $12 \mathrm{~m}$ high, with isolated crown, without interference from branches and foliage of other plants in the same area. The absence of epiphytes, bird nests and colonies of social insects (e.g. ants, bees and termites) was also observed, according to the criteria proposed by Adis et al. (1998), and the methodological procedures of Battirola et al. (2004), and Yamazaki et al. (2016, 2017). The entire diameter at the base of the trees was surrounded by nylon funnels (area of $1 \mathrm{~m}^{2}$ each) distributed according to the reach and architecture of the canopy, totaling $120 \mathrm{~m}^{2}$ of sample area $\left(10 \mathrm{~m}^{2}\right.$ per sampled tree). The base of each collecting funnel contained $92 \%$ alcohol in a plastic collecting vial which was suspended $1 \mathrm{~m}$ from the ground by ropes tied to neighboring trees (Yamazaki et al. 2016, 2017). During the high-water period, the funnels were suspended $1.5 \mathrm{~m}$ from the ground due to raised water levels in the forest (water depth ranged from 0.1 to $0.3 \mathrm{~m}$ ) (Yamazaki et al. 2016, 2017).

Canopy fogging was carried out for $10 \mathrm{~min}$ in each tree, using $0.5 \%$ Lambdacialotrin $\left(\operatorname{Icon}^{\circledR}\right.$ ) synthetic pyrethroxide diluted in two liters of diesel oil at a concentration of $1 \%(20 \mathrm{ml})$, combined with Synergist (DDVP) $0.1 \%(2 \mathrm{ml})$. The thermo-fogger used was Swingfog SN50, which produces a strong jet that is directed from the ground to all parts of the canopy. These procedures always occurred at approximately $06 \mathrm{~h} 00$, when air circulation is less intense, allowing the insecticide cloud to rise slowly through the canopy without dispersing (Adis et al. 1998). Collections were carried out two hours after insecticide application (fogging) on each sampled tree, which the recommended time frame for this action (Adis et al. 1998). Following this procedure, the funnel walls were manually shaken and washed with a spray containing $92 \%$ alcohol and the material was packed in collection flasks located at the funnel bottoms (Yamazaki et al. 2016, 2017).

The collected material was transported to the Biological Collection of Southern Amazon (ABAM), at the Federal University of Mato Grosso, in Sinop - MT, Brazil, to be screened and quantified. All adults were identified at the family level according to Bouchard et al. (2011), Triplehorn et al. (2011) and Casari \& Ide (2012). After this procedure, they were identified at the lowest possible taxonomic levels (Appendix A) at the Collection Reference of the Laboratory of Ecology and Taxonomy of Arthropods (LETA) at the Institute of Biosciences at the Federal University of Mato Grosso, in Cuiabá - MT, and Padre Jesus Santiago Moure Entomological Collection, in the Department of Zoology at the Federal University of Paraná, in Curitiba - PR, where the control material is deposited. The trophic guilds were determined following Arnett (1963), Erwin (1983), Hammond et al. (1996) and Marinoni et al. (2001).

\section{Data analysis}

The variation in Coleoptera abundance and richness between the dry and high-water periods was evaluated based on the $t$ test. To determine the distribution of Coleoptera clusters between the trophic guilds and between the dry and high-water periods, indirect ordination was accomplished via Non-Metric Multidimensional Scaling (NMDS), using the first ordination axis. Ordination was carried out using quantitative data and the Bray-Curtis similarity measure. Species richness was estimated based on the Bootstrap and Jackknife 1 estimators. The Vegan package (Oksanen et al. 2013) was used for the analyses of NMDS and richness estimates. All analyses were performed using R software version 3.0.1 (R Core Team 2013).

\section{Results}

\section{Coleoptera assemblage}

A total of 1,663 coleopterans were sampled from 12 canopies of C. fasciculata, consisting of 1,572 adults $\left(94.5 \% ; 13.1\right.$ ind. $\left./ \mathrm{m}^{2}\right)$ and 91 larvae $\left(5.5 \% ; 0.8\right.$ ind.$\left./ \mathrm{m}^{2}\right)$. The adults were distributed into 38 families and 251 species and morphospecies. The predominant families were Chrysomelidae (447 ind.; 28.4\%; 3.7 ind. $/ \mathrm{m}^{2}$ ), Curculionidae (317 ind.; $20.2 \% ; 2.6$ ind. $\left./ \mathrm{m}^{2}\right)$, Nitidulidae (188 ind.; $12.0 \% ; 1.6$ ind. $\left./ \mathrm{m}^{2}\right)$ and Tenebrionidae (118 ind.; $7.5 \% ; 1.0$ ind. $/ \mathrm{m}^{2}$ ), totaling 1,070 individuals $\left(68.7 \%\right.$ of the total sampled; 8.9 ind. $\left./ \mathrm{m}^{2}\right)$. Among the 38 families, 14 occurred exclusively in the high-water period (e.g. Nitidulidae, Elateridae and Ptilodactylidae), whereas Hydraenidae, Melyridae, Monotomidae and Ptiliidae where the families which occurred only in the dry period (Table 1).

A total of 251 Coleoptera species and morphospecies were identified. The Bootstrap richness estimator indicated that 306 species should be sampled, whereas Jackknife 1 pointed to the possibility of sampling of 380 species. Therefore, the sampling corresponded to 82 and $66 \%$ of the species expected for the assemblage, respectively (Figure 2). The greatest species richness was recorded for Chrysomelidae (40 spp.) and Curculionidae (40 spp.), followed by Staphylinidae (23 spp.), Tenebrionidae (14 spp.) and Elateridae (12 spp.), representing $51.4 \%$ of the total richness obtained. Although Nitidulidae was numerically abundant, only five species were recorded, and Staphylinidae exhibited elevated richness, it showed low abundance (53 ind.; 3.4\%; 0.4 ind. $/ \mathrm{m}^{2}$ ) (Table 1).

Typophorus florigradus Bechyné, 1961 (Chrysomelidae, Eumolpinae) (272 ind.; 17.3\%; 2.3 ind. $\left./ \mathrm{m}^{2}\right)$, Mystrops sp. 3 (Nitidulidae, Nitidulinae) (117 ind.; 7.4\%; 1.0 ind. $/ \mathrm{m}^{2}$ ), Pandeleteius sp. 1 (Curculionidae, Entiminae) (85 ind. $/ 5.4 \% ; 0.7$ ind. $\left./ \mathrm{m}^{2}\right)$, Lechriops sp. 2 (Curculionidae, Conoderinae) (75 ind.; $4.8 \%$; 0.6 ind. $/ \mathrm{m}^{2}$ ) and Antitypona sp. 1 (Chrysomelidae, Eumolpinae) ( 70 ind.; 4.4\%; 0.6 ind./ $\left.\mathrm{m}^{2}\right)$ totaled 619 individuals $\left(37.2 \% ; 5.2\right.$ ind. $\left./ \mathrm{m}^{2}\right)$, corresponding to the most abundant species in this assemblage (Appendix A).

\section{Temporal variation}

A comparison via indirect ordination of the data of the Coleoptera family (NMDS) between the high-water and dry periods revealed a stress index of 0.12 . The result of the $t$ test, which compares the scores of the axis, revealed differences between the distribution of families for the two periods ( $t$ test $=-10.269 ; \mathrm{DF}=8.603 ; \mathrm{p}<0.001$ ) (Figure 3) and also that the high-water and dry periods are different regarding abundance $(\mathrm{t}$ test $=5.329 ; \mathrm{DF}=7.167 ; \mathrm{p}=0.001)$ and species richness $(\mathrm{t}$ test $=4.338 ; \mathrm{DF}=6.853 ; \mathrm{p}=0.004)$ (Figures $4 \mathrm{~A}$ and $\mathrm{B})$.

With regards the abundance of the Coleoptera assemblage, 1,324 individuals were sampled in the high-water period, consisting of 1,251 adults (94.5\%: 20.8 ind. $\left./ \mathrm{m}^{2}\right)$ and 73 larvae $\left(5.5 \% ; 1.2\right.$ ind. $\left./ \mathrm{m}^{2}\right)$. The adults were represented by 34 families and 184 species. The most 
Table 1. Number of individuals $(\mathrm{N})$, relative abundance (\%), density (ind. $\left./ \mathrm{m}^{2}\right)$, richness $(\mathrm{S})$ and trophic guilds of Coleoptera obtained from Callisthene fasciculata canopies in the high-water and dry periods in the Northern Pantanal of Mato Grosso. *Saprophage (S), Fungivore (F), Herbivore (H), Predator (P), Decomposer (D), Feeding habit considered secondary ( ).

\begin{tabular}{|c|c|c|c|c|c|c|c|c|c|c|c|c|c|}
\hline \multirow{2}{*}{ Families/Subfamilies } & \multicolumn{4}{|c|}{ HIGH WATER } & \multicolumn{4}{|c|}{ DRY SEASON } & \multicolumn{4}{|c|}{ TOTAL } & \multirow{2}{*}{$\begin{array}{l}\text { Trophic } \\
\text { Guilds* }\end{array}$} \\
\hline & $\mathrm{N}$ & $\%$ & Ind. $/ \mathrm{m}^{2}$ & $\mathrm{~S}$ & $\mathrm{~N}$ & $\%$ & Ind. $/ \mathrm{m}^{2}$ & $\mathrm{~S}$ & $\mathrm{~N}$ & $\%$ & Ind. $/ \mathrm{m}^{2}$ & $\mathrm{~S}$ & \\
\hline Aderidae & 2 & 0.2 & $<0.1$ & 2 & 4 & 1.2 & 0.1 & 3 & 6 & 0.4 & $<0.1$ & 4 & $\mathrm{~S}$ \\
\hline Anthribidae (Anthribinae) & 2 & 0.2 & $<0.1$ & 2 & 2 & 0.6 & $<0.1$ & 2 & 4 & 0.2 & $<0.1$ & 4 & F \\
\hline Bothrideridae & 20 & 1.6 & 0.3 & 1 & 4 & 1.2 & 0.1 & 1 & 24 & 1.5 & 0.2 & 1 & $\mathrm{H}$ \\
\hline Brentidae (Apioninae) & 8 & 0.6 & 0.1 & 3 & 12 & 3.7 & 0.2 & 5 & 20 & 1.3 & 0.2 & 7 & $\mathrm{H}$ \\
\hline Buprestidae & 2 & 0.2 & $<0.1$ & 2 & 60 & 18.7 & 1.0 & 3 & 62 & 3.9 & 0.5 & 4 & $\mathrm{H}$ \\
\hline Carabidae & 58 & 4.6 & 1.0 & 15 & 13 & 4.0 & 0.2 & 9 & 71 & 4.5 & 0.6 & 19 & $\mathrm{P}$ \\
\hline (Harpalinae) & $(48)$ & $(82.8)$ & $(0.8)$ & (12) & (12) & $(92.3)$ & $(0.2)$ & (8) & $(60)$ & $(84.5)$ & $(0.5)$ & (16) & $\mathrm{P}$ \\
\hline (Paussinae) & (2) & $(3.4)$ & $(<0.1)$ & (1) & - & - & - & - & (2) & $(2.8)$ & $(<0.1)$ & (1) & $\mathrm{P}$ \\
\hline (Trechinae) & (1) & $(1.7)$ & $(<0.1)$ & (1) & - & - & - & - & (1) & (1.4) & $(<0.1)$ & (1) & $\mathrm{P}$ \\
\hline Cerambycidae (Lamiinae) & 3 & 0.2 & $<0.1$ & 1 & - & - & - & - & 3 & 0.2 & $<0.1$ & 1 & $\mathrm{H}$ \\
\hline Chrysomelidae & 424 & 33.9 & 7.1 & 30 & 23 & 7.2 & 0.4 & 18 & 447 & 28.4 & 3.7 & 40 & $\mathrm{H}$ \\
\hline (Eumolpinae) & (353) & $(83.2)$ & $(5.9)$ & (7) & (2) & $(8.7)$ & $(<0.1)$ & (1) & $(355)$ & (79.4) & $(3.0)$ & (7) & $\mathrm{H}$ \\
\hline (Cryptocephalinae) & (12) & $(2.8)$ & $(0.2)$ & (4) & - & - & - & - & (12) & $(2.7)$ & $(0.1)$ & (4) & $\mathrm{H}$ \\
\hline (Galerucinae) & (48) & (11.3) & $(0.8)$ & (12) & (15) & $(65.2)$ & $(0.2)$ & (12) & (63) & $(14.1)$ & $(0.5)$ & (19) & $\mathrm{H}$ \\
\hline (Bruchinae) & (11) & $(4.3)$ & $(0.2)$ & (7) & (6) & $(26.1)$ & $(0.1)$ & (5) & (17) & $(3.8)$ & $(0.1)$ & (10) & $\mathrm{H}$ \\
\hline Ciidae & 4 & 0.3 & 0.1 & 2 & - & - & - & - & 4 & 0.2 & $<0.1$ & 2 & $\mathrm{~F}$ \\
\hline Cleridae & 1 & 0.1 & $<0.1$ & 1 & 3 & 0.9 & $<0.1$ & 2 & 4 & 0.2 & $<0.1$ & 3 & $\mathrm{P}$ \\
\hline Coccinellidae & 3 & 0.2 & $<0.1$ & 2 & 10 & 3.1 & 0.2 & 5 & 13 & 0.8 & 0.1 & 7 & $\mathrm{P}$ \\
\hline (Scymninae) & (1) & $(33.3)$ & $(<0.1)$ & (1) & (10) & $(100.0)$ & $(0.2)$ & (5) & (11) & $(84.6)$ & $(0.2)$ & (6) & $\mathrm{P}$ \\
\hline (Sticholotidinae) & (2) & $(66.7)$ & $(<0.1)$ & (1) & - & - & - & - & (2) & (15.4) & $(<0.1)$ & (1) & $\mathrm{P}$ \\
\hline Corylophidae & 20 & 1.6 & 0.3 & 5 & 4 & 1.2 & 0.1 & 2 & 24 & 1.5 & 0.2 & 5 & $\mathrm{P}$ \\
\hline Cucujidae & 16 & 1.3 & 0.3 & 6 & 3 & 0.9 & $<0.1$ & 3 & 19 & 1.2 & 0.2 & 8 & $\mathrm{P}(\mathrm{F})$ \\
\hline Curculionidae & 220 & 17.6 & 3.7 & 29 & 97 & 30.2 & 1.6 & 18 & 317 & 20.2 & 2.6 & 40 & $\mathrm{H}$ \\
\hline (Baridinae) & (1) & $(0.4)$ & $(<0.1)$ & (1) & (1) & $(1.0)$ & $(<0.1)$ & (1) & (2) & $(0.6)$ & $(<0.1)$ & (2) & $\mathrm{H}$ \\
\hline (Ceutorhynchinae) & (1) & $(0.4)$ & $(<0.1)$ & (1) & - & - & - & - & (1) & $(0.3)$ & $(<0.1)$ & (1) & $\mathrm{H}$ \\
\hline (Conoderinae) & (76) & $(34.5)$ & $(1.3)$ & (2) & (6) & $(6.2)$ & $(0.1)$ & (4) & $(82)$ & $(25.9)$ & $(0.7)$ & (6) & $\mathrm{H}$ \\
\hline (Cryptorhynchinae) & (6) & $(2.7)$ & $(0.1)$ & (4) & (43) & $(44.3)$ & $(0.7)$ & (2) & (49) & $(15.5)$ & $(0.4)$ & (6) & $\mathrm{H}$ \\
\hline (Curculioninae) & (28) & $(12.7)$ & $(0.5)$ & (9) & (16) & $(16.5)$ & $(0.3)$ & (4) & (44) & (13.9) & $(0.4)$ & (11) & $\mathrm{H}$ \\
\hline (Cyclominae) & (1) & $(0.4)$ & $(<0.1)$ & (1) & - & - & - & - & (1) & $(0.3)$ & $(<0.1)$ & (1) & $\mathrm{H}$ \\
\hline (Entiminae) & (91) & (41.4) & $(1.5)$ & (2) & (12) & $(12.4)$ & $(0.2)$ & (1) & (103) & $(32.5)$ & $(0.9)$ & (2) & $\mathrm{H}$ \\
\hline (Erirhininae) & (2) & $(0.9)$ & $(<0.1)$ & (2) & (2) & $(2.1)$ & $(<0.1)$ & (1) & (4) & $(1.3)$ & $(<0.1)$ & (3) & $\mathrm{H}$ \\
\hline (Mesoptiliinae) & (7) & $(3.2)$ & $(0.1)$ & (3) & (2) & $(2.1)$ & $(<0.1)$ & (1) & (9) & $(2.8)$ & $(0.1)$ & (3) & $\mathrm{H}$ \\
\hline (Molytinae) & (1) & $(0.4)$ & $(<0.1)$ & (1) & (1) & $(1.0)$ & $(<0.1)$ & (1) & (2) & $(0.6)$ & $(<0.1)$ & (2) & $\mathrm{H}$ \\
\hline (Platypodinae) & (1) & $(0.4)$ & $(<0.1)$ & (1) & (2) & $(2.1)$ & $(<0.1)$ & (1) & (3) & $(0.9)$ & $(<0.1)$ & (1) & $\mathrm{F}$ \\
\hline (Scolytinae) & (5) & (2.3) & $(0.1)$ & (2) & (12) & $(12.4)$ & $(<0.1)$ & (2) & (17) & (5.4) & $(0.1)$ & (2) & $\mathrm{F}$ \\
\hline Elateridae & 67 & 5.4 & 1.1 & 12 & - & - & - & - & 67 & 4.3 & 0.6 & 12 & $\mathrm{H}$ \\
\hline (Agrypninae) & $(62)$ & $(92.5)$ & $(1.0)$ & (7) & - & - & - & - & $(62)$ & $(92.5)$ & $(0.5)$ & (7) & $\mathrm{H}$ \\
\hline Histeridae & 2 & 0.2 & $<0.1$ & 2 & - & - & - & - & 2 & 0.1 & $<0.1$ & 2 & $\mathrm{P}$ \\
\hline Hydraenidae & - & - & - & - & 1 & 0.3 & $<0.1$ & 1 & 1 & 0.1 & $<0.1$ & 1 & $\mathrm{P}$ \\
\hline Lampyridae & 9 & 0.7 & 0.1 & 4 & - & - & & - & 9 & 0.6 & 0.1 & 4 & $\mathrm{P}$ \\
\hline Latridiidae & 3 & 0.2 & $<0.1$ & 2 & 15 & 4.7 & 0.2 & 5 & 18 & 1.1 & 0.1 & 5 & $\mathrm{~F}$ \\
\hline Limnichidae & 1 & 0.1 & $<0.1$ & 1 & - & - & - & - & 1 & 0.1 & $<0.1$ & 1 & $\mathrm{~S}$ \\
\hline Melolonthidae & 4 & 0.3 & 0.1 & 2 & - & - & - & - & 4 & 0.2 & $<0.1$ & 2 & $\mathrm{H}$ \\
\hline (Melolonthinae) & (1) & $(25)$ & $(<0.1)$ & (1) & - & - & - & - & (1) & $(25)$ & $(<0.1)$ & (1) & $\mathrm{H}$ \\
\hline (Rutelinae) & (3) & (75) & $(<0.1)$ & (1) & - & - & - & - & (3) & $(75)$ & $(<0.1)$ & (1) & $\mathrm{H}$ \\
\hline Melyridae & - & - & - & - & 2 & 0.6 & $<0.1$ & 2 & 2 & 0.1 & $<0.1$ & 2 & $\mathrm{P}$ \\
\hline Monotomidae & - & - & - & - & 1 & 0.3 & $<0.1$ & 1 & 1 & 0.1 & $<0.1$ & 1 & $\mathrm{~F}$ \\
\hline Mordellidae & 2 & 0.2 & $<0.1$ & 2 & - & - & - & - & 2 & 0.1 & $<0.1$ & 2 & $\mathrm{P}$ \\
\hline Nitidulidae (Nitidulinae) & 188 & 15 & 3.1 & 5 & - & - & - & - & 188 & 12 & 1.6 & 5 & $\mathrm{~S}$ \\
\hline Phalacridae & 2 & 0.2 & $<0.1$ & 2 & 3 & 0.9 & $<0.1$ & 3 & 5 & 0.3 & $<0.1$ & 3 & $\mathrm{H}$ \\
\hline Phengodidae & 1 & 0.1 & $<0.1$ & 1 & - & - & - & - & 1 & 0.1 & $<0.1$ & 1 & $\mathrm{P}$ \\
\hline Ptiliidae & - & - & - & - & 1 & 0.3 & $<0.1$ & 1 & 1 & 0.1 & $<0.1$ & 1 & $\mathrm{D}$ \\
\hline Ptilodactylidae & 21 & 1.7 & 0.3 & 1 & - & - & - & - & 21 & 1.3 & 0.2 & 1 & $\mathrm{H}$ \\
\hline Pitnidae & 20 & 1.6 & $<0.1$ & 8 & 19 & 5.9 & 0.3 & 4 & 39 & 2.5 & 0.3 & 8 & $\mathrm{H}$ \\
\hline
\end{tabular}




\begin{tabular}{|c|c|c|c|c|c|c|c|c|c|c|c|c|c|}
\hline Scarabaeidae (Scarabaeinae) & 2 & 0.2 & $<0.1$ & 1 & - & - & - & - & 2 & 0.1 & $<0.1$ & 1 & $\mathrm{D}$ \\
\hline Scydmaenidae & 11 & 0.9 & 0.2 & 3 & 1 & 0.3 & $<0.1$ & 1 & 12 & 0.8 & 0.1 & 4 & $\mathrm{P}$ \\
\hline Silvanidae & 1 & 0,1 & $<0.1$ & 1 & - & - & - & - & 1 & 0.1 & $<0.1$ & 1 & $\mathrm{~F}$ \\
\hline Staphylinidae & 27 & 2.2 & 0.4 & 15 & 16 & 5.0 & 0.3 & 12 & 53 & 3.4 & 0.4 & 23 & $\mathrm{P}$ \\
\hline (Paederinae) & (8) & $(29.6)$ & $(0.1)$ & (3) & (3) & $(18.7)$ & $(<0.1)$ & (3) & (11) & $(20.7)$ & $(0.1)$ & (5) & $\mathrm{P}$ \\
\hline (Pselaphinae) & (2) & $(7.4)$ & $(<0.1)$ & (2) & (2) & $(12.5)$ & $(<0.1)$ & (1) & (4) & $(7.5)$ & $(<0.1)$ & (3) & $\mathrm{F}$ \\
\hline (Scaphidiinae) & (3) & (11.1) & $(<0.1)$ & (1) & (1) & $(6.2)$ & $(<0.1)$ & (1) & (4) & $(7.5)$ & $(<0.1)$ & (1) & $\mathrm{F}$ \\
\hline Tenebrionidae & 96 & 7.7 & 1.6 & 12 & 22 & 6.8 & 0.4 & 6 & 118 & 7.5 & 1.0 & 14 & S \\
\hline (Alleculinae) & (62) & $(69.7)$ & $(1.0)$ & (5) & (10) & $(45.4)$ & $(0.2)$ & (2) & (72) & (64.9) & $(0.6)$ & (5) & $\mathrm{H}$ \\
\hline Zopheridae & 5 & 0.4 & 0.1 & 5 & 1 & 0.3 & $<0.1$ & 1 & 6 & 0.4 & $<0.1$ & 6 & $\mathrm{~F}$ \\
\hline (Colydiinae) & (1) & $(20.0)$ & $(<0.1)$ & (1) & (1) & (100.0) & $(<0.1)$ & (1) & (2) & (33.3) & $(<0.1)$ & (2) & $P(F)$ \\
\hline (Monominae) & (3) & $(60.0)$ & $(<0.1)$ & (3) & - & - & - & - & (3) & $(50.0)$ & $(<0.1)$ & (3) & $\mathrm{H}$ \\
\hline (Zopherinae) & (1) & $(2.00)$ & $(<0.1)$ & (1) & - & - & - & - & (1) & (16.7) & $(<0.1)$ & (1) & $\mathrm{F}$ \\
\hline Total adults & 1,251 & 94.5 & 20.8 & 184 & 321 & 94.7 & 5.3 & 110 & 1,572 & 94.5 & 13.1 & 251 & - \\
\hline Total immatures (larvae) & 73 & 5.5 & 1.2 & - & 18 & 5.3 & 0.3 & - & 91 & 5.5 & 0.8 & - & - \\
\hline TOTAL & 1,324 & 100.0 & 22.1 & 184 & 339 & 100.0 & 5.6 & 110 & 1,663 & 100.0 & 13.9 & 251 & - \\
\hline
\end{tabular}

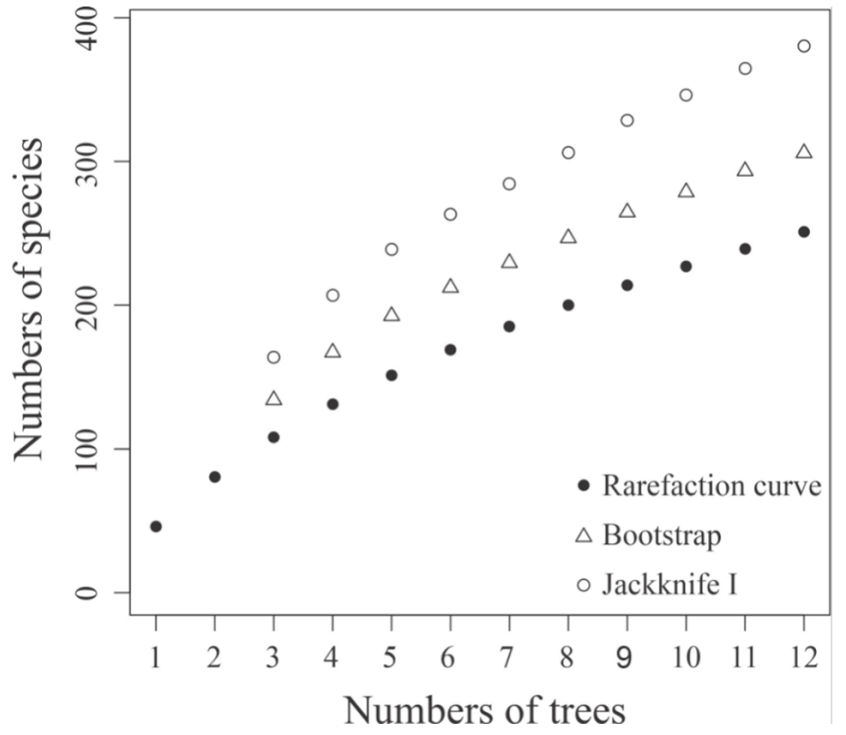

Figure 2. Observed (rarefaction curve) and estimated (Bootstrap and Jackknife 1) species richness of the Coleoptera community associated with Callisthene fasciculata canopies during the high-water (trees 1 to 6 ) and dry (trees 7 to 12) periods in the Northern Pantanal of Mato Grosso.

abundant families were Chrysomelidae (424 ind.; 33.9\%; 7.1 ind. $/ \mathrm{m}^{2}$ ), Curculionidae (220 ind.; 17.6\%; 3.7 ind. $/ \mathrm{m}^{2}$ ) and Nitidulidae (188 ind.; $15.0 \% ; 3.1$ ind. $/ \mathrm{m}^{2}$ ), followed by Tenebrionidae (96 ind.; $7.7 \% ; 1.6$ ind./ $\mathrm{m}^{2}$ ) and Carabidae (58 ind.; $4.6 \% ; 1.0$ ind. $/ \mathrm{m}^{2}$ ) (Table 1). During the dry period, only 339 coleopterans were collected $\left(2.4 \% ; 5.6\right.$ ind. $\left./ \mathrm{m}^{2}\right)$, 321 of which were adult $\left(94.7 \% ; 5.3\right.$ ind. $\left./ \mathrm{m}^{2}\right)$ and 18 larvae $(5.3 \% ; 0.3$ ind. $\left./ \mathrm{m}^{2}\right)$. The adults are distributed into 25 families and 110 species. Curculionidae (97 ind.; 30.2\%; 1.6 ind. $/ \mathrm{m}^{2}$ ) and Buprestidae (60 ind.; $18.7 \% ; 1$ ind. $/ \mathrm{m}^{2}$ ) were the most abundant. Carabidae, Chrysomelidae,

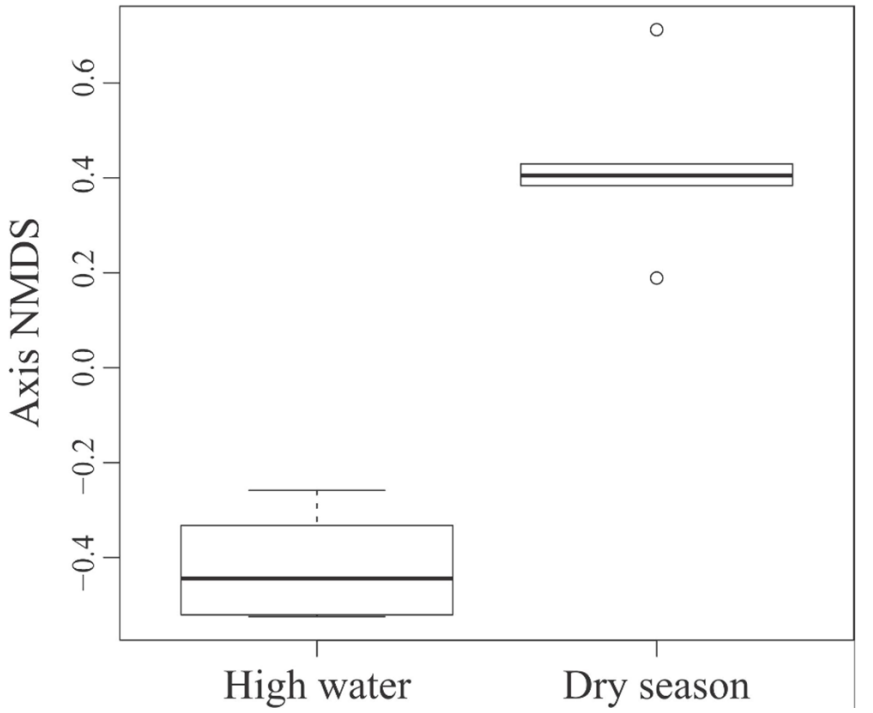

Figure 3. Comparison of scores of the NMDS axis generated from the distribution of 38 Coleoptera families on Callisthene fasciculata between the high-water and dry periods in the Northern Pantanal of Mato Grosso.

Curculionidae and Tenebrionidae had their abundance reduced during the dry period, whereas that of Buprestidae rose in that period.

Among the adult coleopterans, 141 species (56.2\%) occurred exclusively in the high-water period, and 68 species $(27.1 \%)$ were sampled only in the dry period. The other 42 species were common to both seasonal periods (Appendix A). In the high-water period, Chrysomelidae (30 spp.), Curculionidae (29 spp.), Carabidae (15 spp.), Staphylinidae (15 spp.), Elateridae (12 spp.) and Tenebrionidae (12 spp.) represented 62.1\% of the total richness (Table 1). Typophorus florigradus (Chrysomelidae, Eumolpinae) was the dominant species (270 ind.; $21.6 \%$; 4.5 ind. $/ \mathrm{m}^{2}$ ), 

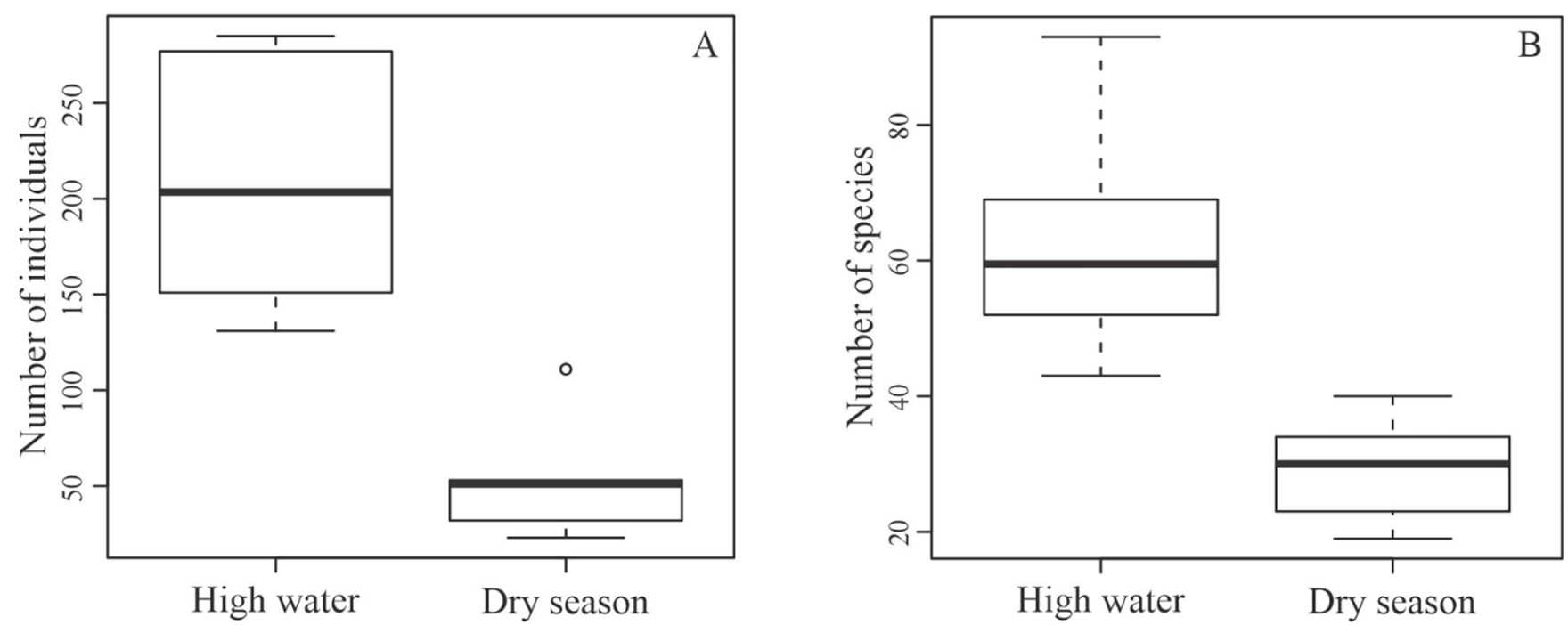

Figure 4. Comparison between abundance (A) and richness (B) of the Coleoptera community on Callisthene fasciculata canopies between the high-water and dry periods in the Northern Pantanal of Mato Grosso.

followed by Mystrops sp. 3 (Nitidulidae, Nitidulinae) (117 ind./9.4\%; 1.9 ind. $/ \mathrm{m}^{2}$ ), Lechriops sp. 2 (Curculionidae, Conoderinae) (75 ind.; $6.0 \% ; 1.2$ ind. $/ \mathrm{m}^{2}$ ), Pandeleteius sp. 1 (Curculionidae, Entiminae) (73 ind.; 5.8\%; 1.2 ind. $/ \mathrm{m}^{2}$ ) and Antitypona sp. 1 (Chrysomelidae, Eumolpinae) (70 ind.; $5.6 \%, 1.2$ ind. $/ \mathrm{m}^{2}$ ) (Appendix A). In the dry period, Chrysomelidae and Curculionidae were the most diversified, with 18 species each, followed by Staphylinidae (12 spp.) and Carabidae (9 spp.) (Table 1). Buprestidae sp. 1 (58 ind.; $18.1 \% ; 1.0$ ind. $/ \mathrm{m}^{2}$ ) and Cryptorhynchini sp. 1 (42 ind.; $13.1 \%$; 0.7 ind. $/ \mathrm{m}^{2}$ ) were the most abundant species in this period.

\section{Trophic guilds}

The coleopterans associated with the C. fasciculata canopies were distributed into five clusters of trophic guilds. Considering the abundance of individuals, herbivores (1,050 ind.; $66.8 \% ; 8.7$ ind. $\left./ \mathrm{m}^{2}\right)$ predominated, followed by saprophages ( 241 ind.; $15.3 \% ; 2.0$ ind. $/ \mathrm{m}^{2}$ ), predators (221 ind.; $14.1 \%$; $\left.1.8 \mathrm{ind} . / \mathrm{m}^{2}\right)$, fungivores ( 57 ind.; $3.6 \%$ and 0.5 ind. $/ \mathrm{m}^{2}$ ) and decomposers ( 3 ind.; $0.2 \% ;<0.1$ ind. $/ \mathrm{m}^{2}$ ). The main herbivores were Chrysomelidae and Curculionidae. The most abundant saprophages corresponded to Nitidulidae and Tenebrionidae. Carabidae and Staphylinidae comprised the most numerous predators, whereas Platypodinae and Scolytinae (Curculionidae) and Latridiidae occurred at the highest frequency among the fungivores. The decomposers were represented by Scarabaeidae and Ptiliidae (Table 1).

In terms of species richness, the herbivores predominated, with 131 species $(52.2 \%)$, followed by predators (78 spp.; 31.1\%). Despite their reduced abundance, fungivores appeared with similar richness (21 spp.; 8.4\%) to that of saprophages (19 spp.; 7.6\%), while only two species were decomposers $(0.8 \%)$. The indirect ordination of behavioral guild data (NMDS) between the high-water and dry periods resulted in a stress index of 0.04 . The result of the $t$ test, which compares the scores of the axis, showed the difference between the distribution of the clusters into guilds for the two periods ( $\mathrm{t}$ test $=-5.571 ; \mathrm{DF}=9.717 ; \mathrm{p}>0.001)$ (Figure 5).

The herbivores were more abundant both in the high-water (836 ind.; $66.8 \% ; 13.9$ ind. $/ \mathrm{m}^{2}$ ) and in the dry period (214 ind.; $66.7 \%$; 3.6

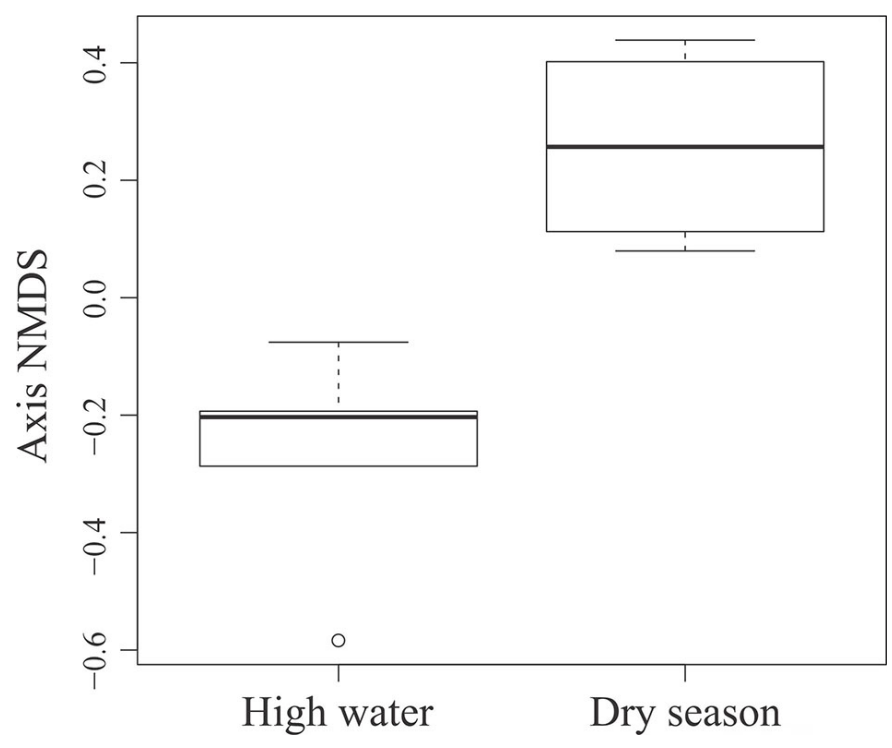

Figure 5. Comparison of the NMDS axis scores generated from the distribution of the five clusters into trophic guilds of Coleoptera on Callisthene fasciculata canopies between the high-water and dry periods in the Northern Pantanal of Mato Grosso.

ind. $\left./ \mathrm{m}^{2}\right)$. In the high-water period, the herbivores were followed by the saprophages (225 ind.; $18.0 \% ; 3.7$ ind. $/ \mathrm{m}^{2}$ ) and predators $(166$ ind.; $13.3 \% ; 2.8$ ind. $/ \mathrm{m}^{2}$ ), whereas the fungivores and decomposers had the lowest abundance ( 24 ind.; $1.9 \% ; 0.4$ ind. $/ \mathrm{m}^{2}$ ). During the dry period, the herbivores were followed by the predator beetles ( 55 ind.; $17.1 \% ; 0.9$ ind. $/ \mathrm{m}^{2}$ ) and fungivores ( 35 ind.; $4.4 \%$; 0.6 ind. $/ \mathrm{m}^{2}$ ), while the saprophages and decomposers were the trophic clusters of lowest representativeness (17 ind.; $5.3 \% ; 0.3$ ind. $/ \mathrm{m}^{2}$ ).

\section{Discussion}

The Coleoptera assemblage associated with canopies of $C$. fasciculata has its temporal dynamics influenced in terms of abundance, 
richness and distribution according to the seasonality of the Pantanal biome. Distinct assemblages occur between the dry and high-water periods, reflecting the specificities of this floodplain as well as association with the phenological characteristics of this host tree. In C. fasciculata, the adult coleopterans were distributed into 38 families and 251 species and morphospecies.

The results obtained in our study are similar to those found by Marques et al. (2006) analyzing Coleoptera assemblages in canopy of $V$. divergens, another tree species that forms monodominant forests in the Pantanal and belongs to the Vochysiaceae family. Marques et al. (2006) obtained 256 species/morphospecies in 32 families of Coleoptera. Different results were obtained by Santos et al. (2003) and Battirola et al. (2014) on A. phalerata Mart. (Arecaceae) canopies in that same region of the Pantanal, showing that palm trees canopies are habitat to Coleoptera assemblages richer in species, when compared to the species of Vochysiaceae. Santos et al. (2003) obtained 326 species/morphospecies in 48 families during the dry season, while Battirola et al. (2014) found 467 species/morphospecies distributed in 43 Coleoptera families during the high-water period. Palm trees differ from other tree types, because of their specific canopy structure and architecture, which is likely due to organic matter accumulation in the remaining leaf sheaths adhered to the plant stem, which provides specific sites of reproduction, feeding and shelter for the associated species, like insects, as well as due to their more stable phenology (Santos et al. 2003, Battirola et al. 2007, Marques et al. 2009).

Canopies can be considered an important habitat model (Nadkarni 1994, Adams et al. 2017). Variations in host plant phenology, including the periods of fructification, flowering and leaf turnover may influence the availability of resources and niches available to the fauna (e.g. Basset et al. 2003b, Castaño-Meneses 2014). Evergreen plants such as palm trees maintain the resource and niche levels more stable throughout the year compared to plants with extreme phenological variations such as $C$. fasciculata. This species has specific periods of leaf turnover, flowering and fructification, and during the high-water period in the Pantanal, its canopy is characterized by full and mature foliage, whereas in the dry period there is a partial leaf fall and the canopy structure is markedly changed (Corsini \& Guarim-Neto 2000). Therefore, it is possible that those variations in the phenology of $C$. fasciculata influenced the total Coleoptera richness, elevating its number during the high-water and reducing it during the dry period in this Pantanal region.

An example of association between host plant phenology and coleopterans can be observed in bruchins (Coleoptera: Chrysomelidae), which synchronize their life cycles to the phenology of their host plants, where flowering provides food to adults and fructification provides substrate to oviposition and larval development (Ribeiro-Costa \& Almeida 2009). In studies conducted in the Pantanal of Mato Grosso, bruchins are always sampled as components of Coleoptera assemblages, but with low abundance among the Chrysomelidae (Marques et al. 2001, 2006, 2007, Santos et al. 2003, Battirola et al. 2014). Another species that can be highlighted in this study is T. florigradus (Chrysomelidae, Eumolpinae). Yamazaki et al. (2020) stated that the record of $T$. florigradus in association with C. fasciculata raises an important discussion about studies on the association between Chrysomelidae and its host plants. Such studies are essential for understanding phylogenetic or ecological theories related to the evolution of host selection and chemical interactions between insects and plants with emphasis on chemical prospecting. Oftentimes, these studies are focused on the host plant rather than on the insects or practices of use, conservation and protection of biodiversity (Flowers \& Janzen 1997).

In C. fasciculata canopies, Chrysomelidae, Curculionidae and Staphylinidae are the families with greatest species richness. The dominance of these coleopterans is commonly observed in studies investigating the forest canopy of different regions (Erwin 1983, Floren \& Linsenmair 1998, Wagner 2000, Santos et al. 2003, Ødegaard 2003, Marques et al. 2006, 2007, 2009, Adis et al. 2010, Battirola et al. 2014). According to Basset (2001), these groups correspond to the invertebrates with greatest richness in the canopy of tropical forests, which is explained by their eating habits, form of exploitation of these forests, and variety of habitats found.

In Uganda, Africa, Wagner (2000) found that Staphylinidae, Curculionidae and Chrysomelidae were the taxa with greatest species richness, whereas Latridiidae, Chrysomelidae and Staphylinidae were the most abundant. Curculionidae and Chrysomelidae were the families with greatest abundance and species richness in studies conducted in Panamá (Ødegaard 2003), similarly to results obtained in the Amazon (Erwin 1983) and in Malasya (Floren \& Linsenmair 1998). Farrel \& Erwin (1988) emphasized that the tree canopy architecture is a key factor determining the diversity of Staphylinidae and other groups of predator beetles, exerting a greater influence than the very floristic composition of the habitat.

Regarding the variation between the dry and high-water periods in C. fasciculata canopies, a higher number of species occurring only once, greater abundance and greater total richness were common to the high-water period. Marques et al. (2006) observed greater abundance and richness of Coleoptera during the high-water period, but a higher number of single-occurrence species during the dry period in $V$. divergens canopies. The authors associated this result with the flowering of the host plant that occurs during this period. Accordingly, the seasonal variation typical of the Pantanal ecosystem might have influenced the structure and composition of the Coleoptera assemblage on C. fasciculata, considering that the structure of canopy arthropod assemblages may vary throughout seasonal periods due to variations imposed by the hydrological regime in that region (Castilho et al. 2005, Marques et al. 2011, Battirola et al. 2014, 2016, 2017a, b, Yamazaki et al. 2016, 2017).

The assemblage organization based on clusters of trophic guilds demonstrated the predominance of herbivorous, saprophages and predator beetles, which corroborates the results obtained by Marques et al. (2006, 2007) and Battirola et al. (2014). Fungivores were also found among the most numerous trophic guilds in the studies of Marques et al. (2006) and Battirola et al. (2014) in the same region, contrasting with the present results. The low representativeness of decomposer beetles also conflicts with data obtained in the same region (Santos et al. 2003, Marques et al. 2007, 2009, 2011).

The distribution of clusters into trophic guilds allows us to evaluate the exploitation of resources by those insects. Callisthene fasciculata occurs in monodominant formations; i.e., forests where over $50 \%$ of the individuals correspond to the same plant species (Connell \& Lowman 1989). This vegetation structure may affect the distribution of resources to the fauna, considering the lower number of tree species in its composition. Because of this factor, resource distribution can be more homogenized and less diversified, facilitating the access to 
and maintenance of species adapted to those conditions over others less adapted and thus dependent on a greater variety of resources (e.g. Southwood 1961, Root 1973).

Overall, it can be concluded that the temporal dynamics of the Coleoptera assemblage associated with C. fasciculata canopies is maintained by the hydrological seasonality of the Pantanal of Mato Grosso, which was evinced by variations in abundance, richness and distribution of the assemblage. Seasonality acts as a primary ecofactor in this biome (Junk et al. 1989, 2006, 2013, Wantzen et al. 2016), regulating the spatial-temporal dynamics of the animal and plant assemblages, exerting direct effects on the vegetation structure and its phenology, which, indirectly, interfere with the dynamics of the assemblages associated with specific plant hosts such as C. fasciculata. Based on those results, we emphasize the need for maintaining and conserving the hydrological conditions of the Pantanal and its vegetation formations to preserve the stability of ecosystems and, consequently, their rich biodiversity associated with this Neotropical floodplain.

\section{Supplementary Material}

The following online material is available for this article:

Appendix A - Species and morphospecies, number of individuals $(\mathrm{N})$, relative abundance $(\%)$ and density $\left(\mathrm{Ind} . / \mathrm{m}^{2}\right.$ ) of adult Coleoptera obtained from Callisthene fasciculata canopies in the high-water and dry periods in the northern Pantanal of Mato Grosso, Brazil.

\section{Acknowledgments}

The authors thank the researchers Angélico F. Asenjo Flores, Daiara Manfio, Isaac R. Jorge, Cibele S. Ribeiro-Costa, Lúcia Massutti de Almeida, Fernando Z. Vaz de Mello and José Adriano Giorgi for the taxonomic identifications. Thanks to the Coordenação de Aperfeiçoamento de Pessoal de Nível Superior (CAPES, Finance code 001) and the Fundação de Amparo à Pesquisa do Estado de Mato Grosso (FAPEMAT Grant no. 737641/2008); the Núcleo de Estudos em Biodiversidade da Amazônia Mato-grossense (NEBAM/UFMT/ Sinop); and the Laboratório de Ecologia e Taxonomia de Artrópodes (LETA/IB/UFMT).

\section{Author Contributions}

Lúcia Yamazaki: Substantial contribution in the concept and design of the study; Contribution to data analysis and interpretation; Contribution to manuscript preparation; Contribution to critical revision, adding intellectual content.

Vanessa França Vindica: Contribution to data analysis and interpretation; Contribution to manuscript preparation; Contribution to critical revision, adding intellectual content.

Germano Henrique Rosado-Neto: Substantial contribution in the concept and design of the study; Contribution to manuscript preparation; Contribution to critical revision, adding intellectual content.

Marinêz Isaac Marques: Substantial contribution in the concept and design of the study; Contribution to data collection; Contribution to data analysis and interpretation; Contribution to manuscript preparation; Contribution to critical revision, adding intellectual content.
Leandro Dênis Battirola: Substantial contribution in the concept and design of the study; Contribution to data collection; Contribution to data analysis and interpretation; Contribution to manuscript preparation; Contribution to critical revision, adding intellectual content.

\section{Conflicts of interest}

The authors declare that they have no conflict of interest related to the publication of this manuscript.

\section{Ethics}

The authors confirm that the manuscript has been submitted solely to this journal and is not published, in press, or submitted elsewhere; Confirm that all the research meets the ethical guidelines, including adherence to the legal requirements of the study country. Confirm that you have prepared a complete text minus the title page, acknowledgments, and any running headers with author names, to allow blinded review.

\section{Data availability}

The data is not yet available on digital platforms, however all the material is deposited in Entomological collections as reported in the manuscript.

\section{References}

ADAMS, B.J., SCHNITZER, S.A. \& YANOVIAK, S.P. 2017. Trees as islands: canopy ant species richness increases with the size of liana-free trees in a Neotropical forest. Ecography 40:1067-1075.

ADIS, J. 1988. On the abundance and density of terrestrial arthropods in Central Amazonian dryland forest. J. Trop. Ecol. 4:19-24.

ADIS, J., BASSET, Y., FLOREN, A., HAMMOND, P. \& LINSENMAIR, K.E. 1998. Canopy fogging of an overstory tree - recommendations for standardization. Ecotropica 4:93-97.

ADIS, J., ERWIN, T.L., BATTIROLA, L.D. \& KETELHUT, S.M. 2010. The importance of Amazonian floodplain forests for animal biodiversity: Beetles in canopies of floodplain and upland forests. In Amazon floodplain forests: Ecophysiology, biodiversity and sustainable management (W.J. Junk, M.T.F. Piedade, F. Wittmann, J. Schöngar \& P. Parolin, eds.). Springer, Dordrecht, p.313-325.

ARNETT, R.H.JR. 1963. The beetles of the United States. The Catholic University of America Press, Washington.

BASSET, Y. 1992. Host specificity of arboreal and free-living insect herbivores in rain forests. Biol. J. Linn Soc. 47:115-133.

BASSET, Y. 2001. Invertebrates in the canopy of tropical rain forests: How much do we really know? Plant Ecol. 153:87-107.

BASSET, Y., HORLYCK, V. \& WRIGHT, J. 2003a. Forest canopies and their importance. In Studying forest canopies from above: The International Canopy Crane Network (Y. Basset, V. Horlyck \& J. Wright, eds.). Editorial Panamericana de Colombia, Bogotá, p.27-34.

BASSET, Y., NOVOTNY, V., MILLER, S.E. \& KITCHING, R.L. 2003 b. Arthropods of tropical forest. Spatio-temporal dynamics and resource use in the canopy. Cambridge University Press, Cambridge.

BATTIROLA, L.D., MARQUES, M.I., ADIS, J. \& BRESCOVIT, A.D. 2004. Aspectos ecológicos da comunidade de Araneae (Arthropoda, Arachnida) em copas da palmeira Attalea phalerata Mart. (Arecaceae) no Pantanal de Poconé, Mato Grosso, Brasil. Rev. Bras. Entomol. 48:421-430.

BATTIROLA, L.D., ADIS, J., MARQUES, M.I. \& SILVA, F.H.O. 2007. Comunidade de artrópodes associados a copas de Attalea phalerata Mart. (Arecaceae) durante o período de cheia no Pantanal de Poconé, MT. Neotrop. Entomol. 36:640-651. 
BATTIROLA, L.D., SANTOS, G.B., ROSADO-NETO, G.H. \& MARQUES, M.I. 2014. Coleoptera (Arthropoda, Insecta) associados às copas de Attalea phalerata Mart. (Arecaceae) no Pantanal de Poconé, Mato Grosso, Brasil. EntomoBrasilis 7:20-28.

BATTIROLA, L.D., BATISTELLA, D.A., ROSADO-NETO, G.H., BRESCOVIT, A.D. \& MARQUES, M.I. 2016. Spider assemblage (Arachnida: Araneae) associated with canopies of Vochysia divergens (Vochysiaceae) in the northern region of the Brazilian Pantanal. Zoologia (Curitiba) 33:1-9.

BATTIROLA, L.D., ROSADO-NETO, G.H., BATISTELLA, D.A., MAHNERT, V., BRESCOVIT, A.D. \& MARQUES, M.I. 2017a. Vertical and time distribution of Pseudoscorpiones (Arthropoda: Arachnida) in a floodplain forest in the Brazilian Pantanal. Rev. Biol. Trop. 65:445-459.

BATTIROLA, L.D., SANTOS, G.B., MEURER, E., CASTILHO, A.C.C., MAHNERT, V., BRESCOVIT, A.D. \& MARQUES, M.I. 2017b. Soil and canopy Pseudoscorpiones (Arthropoda, Arachnida) in a monodominant forest of Attalea phalerata Mart. (Arecaceae) in the Brazilian Pantanal. Stud. Neotrop. Fauna E. 52:87-94.

BOUCHARD, P., BOUSQUET, Y., DAVIES, A.E., ALONSO-ZARAZAGA, M.A., LAWRENCE, J.F., LYAL, C.H.C., NEWTON, A.F., REID, C.A.M., SCHMITT. M., ŚLIPIŃSKI, A.S. \& SMITH, A.B.T. 2011. Family-group names in Coleoptera (Insecta). Zookeys 88:1-972.

CARNEIRO, A.C., BATISTELLA, D.A., BATTIROLA, L.D. \& MARQUES, M.I. 2016. Pitfall traps and mini-Winkler Extractor as complementary methods to sample soil Coleoptera. Neotrop. Entomol. 45:28-32.

CASARI, S.A. \& IDE, S. 2012. Coleoptera Linnaeus, 1758. In Insetos do Brasil: Diversidade e Taxonomia (J.A. Rafael, G.A.R., Melo, C.J.B. Carvalho, S.A. Casari \& R. Constantino, eds.). Holos Editora, Ribeirão Preto, p.454-535.

CASTAÑO-MENESES, G. 2014. Trophic guild structure of a canopy ants community in a Mexican tropical deciduous forest. Sociobiology 61:35-42.

CASTILHO, A.C.C., MARQUES, M.I., ADIS, J. \& BRESCOVIT, A.D. 2005. Distribuição sazonal e vertical de Araneae em área com predomínio de Attalea phalerata Mart. (Arecaceae), no Pantanal de Poconé, Mato Grosso, Brasil. Amazoniana 18:215-239.

CONNELL, J.H. \& LOWMAN, M.D. 1989. Low-diversity tropical rain forest: some possible mechanisms for their existence. American Natur. 134:88-119.

CORSINI, E. \& GUARIM-NETO, G. 2000. Aspectos ecológicos da vegetação de "carvoal (Callisthene fasciculata (Spr.) Mart.) no Pantanal mato-grossense. In Anais do III Simpósio sobre recursos naturais e socioeconômicos do Pantanal. Corumbá, Embrapa/UFMS 1:1-52.

CUSTÓDIO, L.N., CARMO-OLIVEIRA, R., MENDES-RODRIGUES, C. \& OLIVEIRA, P.E. 2014. Pre-dispersal seed predation and abortion in species of Callisthene and Qualea (Vochysiaceae) in a Neotropical savanna. Acta Bot. Bras. 28:309-320.

ERWIN, T.L. 1983. Beetles and other insects of tropical forest canopies at Manaus, Brazil, sampled by insecticidal fogging. In Tropical Rainforest: Ecology and Management (S.L. Sutton, T.C. Whitmore \& A.C. Chadwick, eds.). Blackwell Scientific Publications, Oxford, p.59-75.

ERWIN, T.L. 2013. Forest canopies, animal diversity. In Encyclopedia of Biodiversity (S.A. Levin ed.). Academic Press, San Diego, p.511-515.

FARRELL, B.D. \& ERWIN, T.L. 1988. Leaf-Beetle community structure in an Amazonian rainforest canopy. In Biology of Chrysomelidae (P. Jolivet, E. Petitpieree \& T.H. Hsiao, eds.). Kluwer Academic Publishers, Dordrecht, p.73-90.

FLOREN, A. \& LINSENMAIR, K.E. 1998. Non-equilibrium communities of Coleoptera in trees in a lowland rain forest of Borneo. Ecotropica 4:55-67.

FLOWERS, R.W. \& JANSEN, D.H. 1997. Feeding records of Costa Rican leaf beetles (Coleoptera: Chrysomelidae). Florida Entomol. 80:334-366.

FOTIS, A.T., MORIN, T.H., FAHEY, R.T., HARDIMAN, B.S., BOHRER, G. \& CURTIS P.S. 2018. Forest structure in space and time: Biotic and abiotic determinants of canopy complexity and their effects on net primary productivity. Agric. For. Meteorol. 250/251:181-191.

HAMMOND, P.M., KITCHING, R.L. \& STORK, N.E. 1996. The composition and richness of the tree-crown Coleoptera assemblage in an Australian subtropical forest. Ecotropica 2:99-108.
HASENACK, H., CORDEIRO, J.L.P. \& HOFMANN, G.S. 2003. O clima da RPPN SESC Pantanal. UFRGS, Porto Alegre.

HECKMAN, C.W. 1998. The Pantanal of Poconé - Biota and ecology in the northern section of the world's largest pristine wetland. Kluwer Academic Publishers, Dordrecht.

JUNK, W.J., BAYLEY, P.B. \& SPARKS, R.E. 1989. The flood pulse concept in river-floodplain systems. In Proceedings International Large River Symposium (LARS) (D.P. Dodge, ed.). Fishiries and Aquatic Science, Ottawa, p.110-127.

JUNK, W.J., NUNES-DA-CUNHA, C., WANTZEN, K.M., PETERMANN, P., STRÜSSMANN, C., MARQUES, M.I. \& ADIS, J. 2006. Biodiversity and its conservation in the Pantanal of Mato Grosso, Brazil. Aquatic Sci. 68:278-309.

JUNK, W.J., PIEDADE, M.T.F., LOURIVAL, R., WITTMANN, F., KANDUS, P., LACERDA, L.D., BOZELLI, R.L., ESTEVES, F.A., NUNES-DACUNHA, C., MALTCHIK, L., SCHOENGART, J., SCHAEFFERNOVELLI, Y. \& AGOSTINHO, A.A. 2013. Brazilian wetlands: Definition, delineation and classification for research, sustainable management and protection. Aquat. Conserv. 24:5-22.

LAWRENCE, J.F. \& BRITTON, E.B. 1991. Coleoptera. In CSIRO Division of Entomology (ed.) The insects of Australia. Melbourn University Press, Carlton, p.543-683.

MARINONI, R.C. 2001. Os grupos tróficos em Coleoptera. Rev. Bras. Zool. 18:205-224.

MARINONI, R.C., GANHO, N.G., MONNÉ, M.L. \& MERMUDES, J.R.M. 2001. Hábitos Alimentares em Coleoptera (Insecta). Holos Editora, Ribeirão Preto.

MARQUES, M.I., ADIS, J., NUNES-DA-CUNHA, C. \& SANTOS, G.B. 2001. Arthropod biodiversity in the canopy of Vochysia divergens Pohl (Vochysiaceae), a forest dominant in the Brazilian Pantanal. Stud. Neotrop. Fauna E. 36:205-210.

MARQUES, M.I., ADIS, J., SANTOS, G.B. \& BATTIROLA, L.D. 2006. Terrestrial arthropods from tree canopies in the Pantanal of Mato Grosso, Brazil. Rev. Bras. Entomol. 50:257-267.

MARQUES, M.I., ADIS, J., BATTIROLA, L.D., BRESCOVIT, A.D., SILVA, F.H.O. \& SILVA, J.L. 2007. Composição da comunidade de artrópodes associada à copa de Calophyllum brasiliense Cambess. (Guttiferae) no Pantanal mato-grossense, Mato Grosso, Brasil. Amazoniana 19:131-148.

MARQUES, M.I., SANTOS, G.B., BATTIROLA, L.D. \& TISSIANI, A.S.O. 2009. Entomofauna associada à matéria orgânica em bainhas foliares de Attalea phalerata Mart. (Arecaceae), na região norte do Pantanal de Mato Grosso. Acta Biol. Paran. 38:93-112.

MARQUES, M.I., ADIS, J., BATTIROLA, L.D., SANTOS, G.B. \& CASTILHO, A.C.C. 2011. Arthropods associated with a forest of Attalea phalerata Mart. (Arecaceae) palm trees in the northern Pantanal of the Brazilian state of Mato Grosso. In The Pantanal of Mato Grosso: Ecology, biodiversity and sustainable management of a large Neotropical seasonal wetland (W.J. Junk, C.J da Silva, C. Nunes-da-Cunha \& K.M. Wantzen, eds.). Pensof, Sofia-Moscow, p.431-468.

MARQUES, M.I., SANTOS, G.B. \& BATTIROLA, L.D. 2014. Cerambycidae (Insecta, Coleoptera) associados à Vochysia divergens Pohl. (Vochysiaceae) na região norte do Pantanal de Mato Grosso, Brasil. EntomoBrasilis 7:159-160.

MARQUES, M.I., FIGUEIREDO, A.M., SANTOS, G.B., SOUSA, W.O., IDE, S. \& BATTIROLA, L.D. 2016. Diversity of soil beetles (Hexapoda, Coleoptera) in an area at the Pantanal of Poconé, Mato Grosso, Brazil. EntomoBrasilis 9:89-96.

NADKARNI, N.M. 1994. Diversity of species and interactions in the upper tree canopy of forest ecosystems. American Zool. 34:70-78.

NOVOTNY, V. \& BASSET, Y. 2005. Host specificity of insect herbivores in the tropical forest. Proc. R. Soc. 272:1083-1090.

NUNES-DA-CUNHA, C. \& JUNK, W.J. 2014. Classificação dos macrohabitats do Pantanal Mato-grossense. In Definição e classificação das áreas úmidas (AUs) brasileiras, base científica para uma nova política de proteção e manejo sustentável (C. Nunes-da-Cunha, M.T.F. Piedade \& W.J. Junk, eds.). INCT-INAU - EdUFMT, Cuiabá, p. 13-76. 
ØDEGAARD, F. 2003. Taxonomic composition and host specificity of phytophagous beetles in a dry forest in Panama. In Arthropods of Tropical Forests: Spatio-temporal Dynamics and Resource Use in the Canopy (Y. Basset, V. Novotny, S.E. Miller \& R.L. Kitching, eds.). Cambridge University Press, Cambridge, p.220-236.

ØDEGAARD, F. 2004. Species richness of phytophagous beetles in the tropical tree Brosimum utile (Moraceae): the effects of sampling strategy and the problem of tourists. Ecol. Entomol. 29:76-88.

OKSANEN, J., BLANCHET, F.G., KINDT, R., LEGENDRE, P., MINCHIN, P.R., O'HARA, R.B., SIMPSON, G.L., SOLYMOS, M.P., STEVENS, H.H. \& WAGNER, H. 2013. Vegan: Community Ecology. Package. R package version 2.0-8. http://CRAN.R-project.org/package=vegan (last access in november 2014).

POTT, A. \& POTT, V.J. 1994. Plantas do Pantanal. Embrapa-SPI, Corumbá.

R CORE TEAM. 2013. R: A language and environment for statistical computing. R Foundation for Statistical Computing, Vienna, Austria. http://www.Rproject.org/> (last access in november 2014).

RIBEIRO-COSTA, C.S. \& ALMEIDA, L.M. 2009. Bruchinae (Coleoptera: Chrysomelidae). In Bioecologia e nutrição de insetos: base para o manejo integrado de pragas (A.R. Panizzi \& J.R.P, Parra, eds.). Embrapa Informação Tecnológica, Brasília, p.523-567.

ROOT, R.B. 1973. Organization of a plant-arthropod association in simple and diverse habitats: the fauna of collards (Brassica oleracea). Ecol. Monogr. 43:95-124.

SANTOS, G.B., MARQUES, M.I., ADIS, J, \& MUSIS, C.R. 2003. Artrópodos associados à copa de Attalea phalerata Mart. (Arecaceae), na região do Pantanal de Poconé-MT. Rev. Bras. Entomol. 47:211-224.

SOUTHWOOD, T.R.E. 1961. The number of species of insects associated with various trees. J. Animal Ecol. 30:1-8.

TOMAS, W.M., ROQUE, F.O., MORATO, R.G., MEDICI, P.E., CHIARAVALlOTI, R.M., TORTATO, F.R., PENHA, J.M.F. et al. 2019. Sustainability agenda for the Pantanal Wetland: Perspectives on a collaborative interface for Science, Policy, and Decision-Making. Trop. Conserv. Sci. 12:1-30.
TRIPLEHORN, C., JOHNSON, N.B. \& DELONG, S. 2011. Estudo dos Insetos. Editora Cengage Learning, São Paulo.

WAGNER, T. 2000. Influence of forest type and tree species on canopy-dwelling beetles in Budongo forest, Uganda. Biotropica 32:502-514.

WANTZEN, K.M., MARCHESE, M.R., MARQUES, M.I. \& BATTIROLA, L.D. 2016. Invertebrates in Neotropical Floodplains. In Invertebrates in freshwater wetlands: An international perspective on their ecology (D. Batzer \& D. Boix, eds.). Springer International Publishing, Switzerland, p.493-524.

YAMAZAKI, L., DAMBROS, J., MEURER, E., VINDICA, V.F., DELABIE, J.H.C., MARQUES, M.I. \& BATTIROLA, L.D. 2016. Ant community (Hymenoptera: Formicidae) associated with Callisthene fasciculata (Spr.) Mart. (Vochysiaceae) canopies in the Pantanal of Poconé, Mato Grosso, Brazil. Sociobiology 63:735-743.

YAMAZAKI, L, VINDICA, V.F., BRESCOVIT, A.D., MARQUES, M.I. \& BATTIROLA, L.D. 2017. Temporal variation in the spider assemblage (Arachnida, Araneae) in canopies of Callisthene fasciculata (Vochysiaceae) in the Brazilian Pantanal biome. Iheringia. Ser. Zool. 107:1-9.

YAMAZAKI, L., SOUSA, W.O., ROSADO-NETO, G.H., MARQUES, M.I. \& BATTIROLA, L.D. 2020. First report of Typophorus florigradus Bechyné \& Špringlová, 1961 (Chrysomelidae, Eumolpinae) on Callisthene fasciculata (Spr.) Mart. (Vochysiaceae) in the Brazilian Pantanal. Sci. Elec. Arch. 13(8):http://dx.doi.org/10.36560/13820201154.

Received: 05/03/2020

Revised: 10/10/2020

Accepted: 10/11/2020

Published online: 18/12/2020 